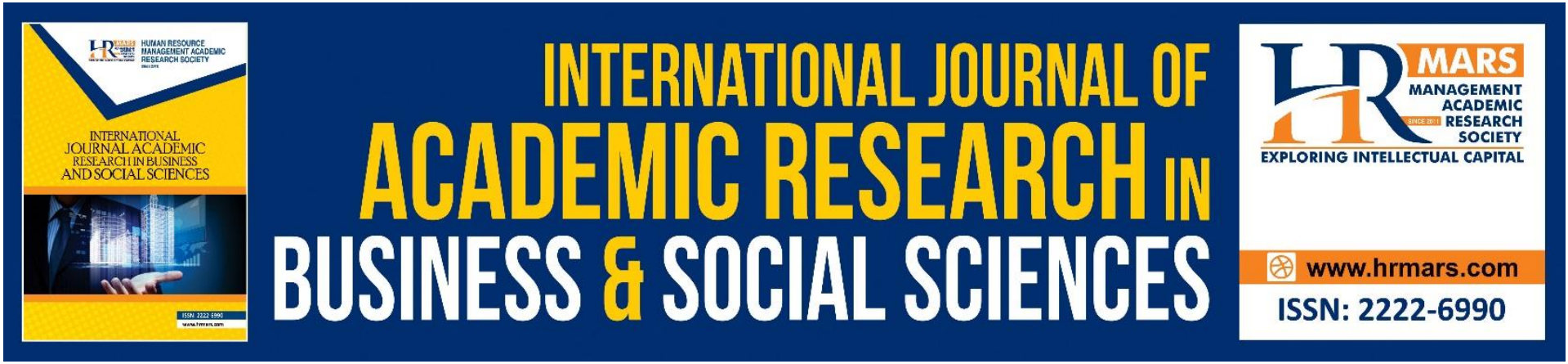

\title{
Determination of Respondents in the Method of Hadith Collection Based on Selected Practice of Imam Bukhari
}

\section{Shahir Akram Hassan}

To Link this Article: http://dx.doi.org/10.6007/IJARBSS/v11-i11/11558

DOI:10.6007/IJARBSS/v11-i11/11558

Received: 07 September 2021, Revised: 10 October 2021, Accepted: 26 October 2021

Published Online: 04 November 2021

In-Text Citation: (Hassan, 2021)

To Cite this Article: Hassan, S. A. (2021). Determination of Respondents in the Method of Hadith Collection Based on Selected Practice of Imam Bukhari. International Journal of Academic Research in Business and Social Sciences, 11(11), $597-606$.

\section{Copyright: @ 2021 The Author(s)}

Published by Human Resource Management Academic Research Society (www.hrmars.com)

This article is published under the Creative Commons Attribution (CC BY 4.0) license. Anyone may reproduce, distribute, translate and create derivative works of this article (for both commercial and non-commercial purposes), subject to full attribution to the original publication and authors. The full terms of this license may be seen at: http://creativecommons.org/licences/by/4.0/legalcode

Vol. 11, No. 11, 2021, Pg. $597-606$

Full Terms \& Conditions of access and use can be found at http://hrmars.com/index.php/pages/detail/publication-ethics 


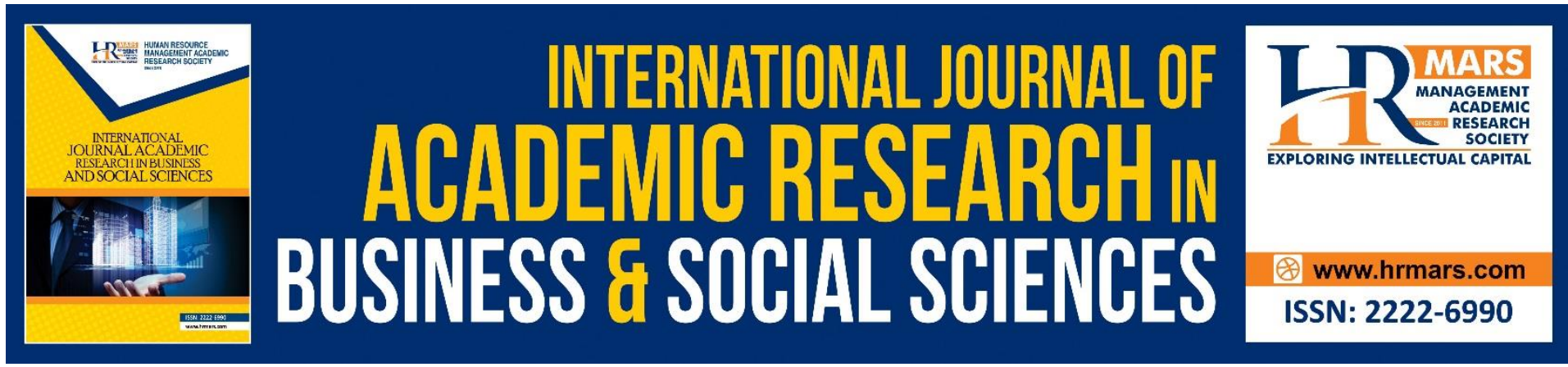

\title{
Determination of Respondents in the Method of Hadith Collection Based on Selected Practice of Imam Bukhari
}

\author{
Shahir Akram Hassan \\ Centre for Islamic Development Management Sudies (ISDEV), Universiti Sains Malaysia, \\ 11800 USM, Penang, Malaysia.
}

\begin{abstract}
This article examines the method of hadith collection based on the technical aspects of data collection, especially sahih hadith. The method of collecting hadith that is thorough and has its own collecting method is suitable to be utilized in situations where the conditions of the authenticity of hadith are very strict according to the scholars of hadith. This method has been recognized by Islamic scholars for determining the quality of a hadith to be accepted in argumentative exchange. One of the outstanding technical aspects of this method is the determination of the respondent or informant. Determination of respondents or informants here means the method of selecting a section of the population for the purpose of making inferences or conclusions about the entire population. This prompted this article to be written primarily to look at the technical aspects of determining respondents based on hadith collection methods to be absorbed into the discipline of Islamic-based research methods. The question is how to determine the respondents according to the collection of hadith? Is the method of determining respondents from this method of collecting hadith suitable to be applied in current research? This article first examines the technical aspects of determining respondents in hadith collection methods. Second, to analyze the application of respondent determination of hadith collection method in current research methods. The writing of this article only involved document review and qualitative content analysis was conducted to analyze the data obtained. The results of the analysis found that the five conditions of authentic hadith are very relevant and suitable to be used as a method of determining respondents or informants in conducting research.
\end{abstract}

Keywords: Determination of Respondents, Informants, Data Collection Methods, Hadith Data Collection Methods, Islamic-Based Research Methods

\section{Introduction}

Research methods essentially refer to specific techniques for obtaining data (Greener, 2008). The data collection method is one of the important strategies carried out by researchers to obtain appropriate information and data to answer the research objectives and questions. According to Hassan (2019), the method of collecting Hadith can be applied as a method of data collection in conducting research. Based on the discussion on the definition of the hadith 
itself, at least five methods of data collection have been identified that can be applied, namely the interview method, questionnaire, participatory observation, non-participatory observation, and silent agreement method. This method of collecting hadith is seen as very thorough and has its own method of collection that has the potential to be utilized in current research. Among its salient technical aspects is the determination of the respondent or informant. Determination of respondents or informants here means a method to select a section of the population for the purpose of making inferences or conclusions about the entire population in conducting research.

As a follow-up study, this article intends to examine the respondent determination technique by previous hadith scholars. One of them is a hadith scholar who is respected for his accuracy. The book of Shahih Bukhari is agreed to be the most authentic book on earth after the Holy Qur'an (Al-Shamali, 2002). The question is how to determine the respondents according to the collection of hadith? Is the method of determining respondents from this method of collecting hadith suitable to be applied in current research? This article first examines the technical aspects of determining respondents according to hadith collection methods. Second, to analyze the application of respondent determination of hadith collection method in current research methods. The document review method is used in the data collection method and the qualitative content analysis method is used to analyze the findings that have been collected.

The method of collection of hadith in the article discusses briefly based on the method of collection of authentic hadith. Specifically, this article is divided into four parts. First, the introduction of hadith. Second, the process of collection and the conditions of authentic hadith according to Imam Bukhari. Third, the determination of respondents in the method of hadith collection based on the practice of Imam Bukhari, and fourth, the conclusions and recommendations of future studies.

\section{Methodology}

This article uses a qualitative approach to achieve the set objectives. The data were collected through documents related to hadith knowledge and then analyzed using content analysis methods.

\section{Introduction to Hadith}

Hadith in terms of language means new. Based on the terminology, the hadith is: "Anything that is attributed to Rasulullah s.a.w. from words, deeds, consent or attributes whether the nature of events or morals and prophetic biography either before or after becoming a Prophet" (Abdullah, 1986).

Hadith are divided into three classifications depending on the conditions set by the scholars of hadith. First, hadith sahih (authentic), hadith hasan (good) and third, hadith dhaif (weak). Hadith maudu' (fabricated) is not recognized as hadith because hadith maudu' is a fabrication and deception against the Prophet s.a.w.. For this paper, the discussion focuses on the Collection Process and Conditions of Sahih Hadith according to Imam Bukhari. Imam Bukhari was chosen because he was one of the respected hadith scholars for his thoroughness in the 
method of determining Sahih hadith. The book of Shahih Bukhari is agreed upon as the most authentic book on earth after the Qur'an (Al-Shamali, 2002).

\section{The Process of Collection and Conditions of Sahih Hadith according to Imam Bukhari}

An authentic hadith is a hadith that has a continuous chain, is narrated by a fair and dhabit narrator (accurate in narrating a hadith either through the strength of memory or the accuracy of its record), and is free from contradictions between narrators (syaz) and defect ('illah). This definition is mentioned by hadith scholars such as Ibn-Solah, Ibn-Kathir, Imam Nawawi, and others. In short, hadith scholars agree that there are five conditions for sahih hadith. First, connected Isnaad. The second and third, narrated by a precise (dhabit) and trustworthy (al-'adaalah) narrator. The fourth and fifth are free from irregularities (syaz) and defect ('illah) (al-Shamali, 2002).

A continuous chain (Isnaad) is when there is an indication or can be proven each narrator in the chain hears the hadith directly from his teacher from the beginning to the end of the chain. The narrator is fair, that is, a person who can control himself with taqwa and stay away from things that are wicked and heretical. The narrator meets the following five characteristics. First, Muslims. Second, adult. Third, fully in control of their mental faculties. Fourth, not fasiq, that is, free from guilt for major sins, and not prone to minor sins. Fifth, maintaining dignity such as not associating with people of low dignity, not being excessive in joking, and not urinating on the side of the road (al-Shamali, 2002).

The narrator is dhabit, that is, a person who memorizes correctly, is free from mistakes or doubts, and is able to present what he memorizes when asked at any time. Dhabit is divided into two, namely Dhabit Sodri and Dhabit Kitabi. Dhabit Sodri is a narrator who memorizes what he hears and is able to tell what he hears and memorizes as he hears it at any time. Dhabit Kitabi, on the other hand, is the narrator who really keeps his notes from being lost, stolen, altered, or distorted from the moment he records them until he is asked to submit his notes (Salleh, 1993).

Free from contradiction (syaz) means not in contrary to other narrations narrated by more reliable narrators (thiqah). A syaz hadith is a hadith narrated by a narrator who is thiqah but is contrary to other hadith narrated by a narrator who is more thiqah or more followers or narrators under him and is not collected. Free from defects, that is, any defect ('illah) that can prevent a hadith from reaching the degree of sahih, for example, contained in the chain of hadith a fasiq person.

From the five conditions of sahih hadith presented above, Figure 1 shows the process of collecting sahih hadith based on the conditions of sahih hadith. 


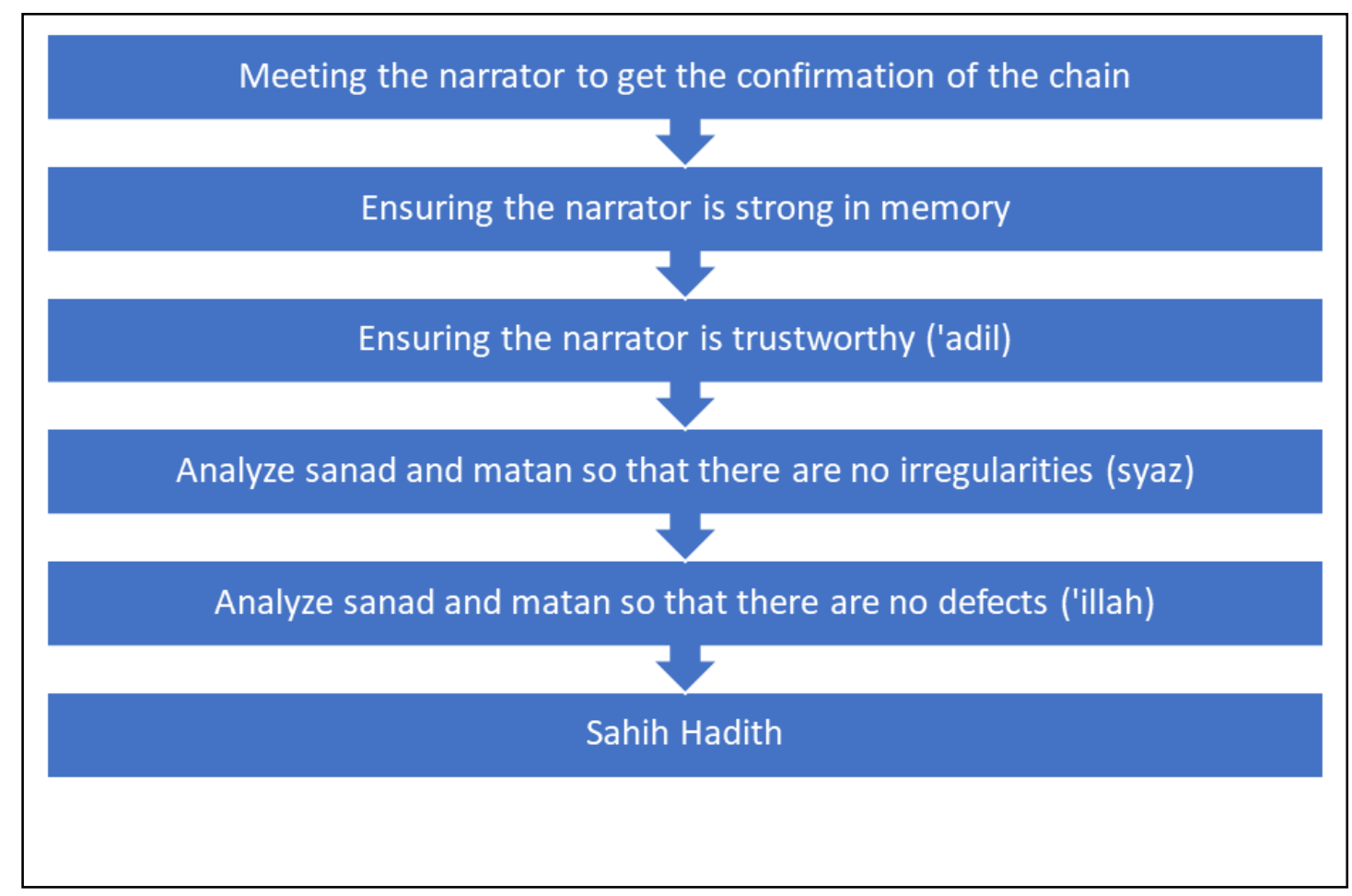

Figure 1: Sahih Hadith Collection Process based on its Conditions

Usually, the process of collecting hadith begins when a hadith collector wants to collect hadith or confirm from the narrator that he has heard a piece of hadith. Then the hadith collector will identify the desired narrator and travel to listen to the hadith directly from the narrator as required to make the chain connected. This has become a habit for a hadith collector. Imam Bukhari once said:

"I have visited Syria, Egypt, and the Peninsula twice each, to Basrah four times, settled in the Hijaz (Mecca and Medina) for six years and it is impossible to count how many times I have visited Kufa and Baghdad to meet expert scholars of hadith."

In determining the signs of a continuous chain, usually, the narrator will state clearly on the chain by using the parables of haddathana (has said to us), haddathani (has said to me), akhbarana (has been reported to us), 'an (of) or anna (indeed). If there is no clear confession to prove that the narrator listened directly, a hadith will not be accepted as a hadith that continues its chain because the narrator did not listen to the hadith directly (Salleh, 1993).

When embarking on a journey, the hadith collector usually knows who and where to go. Apart from that, there are some things that need to be taken into account, especially things that involve the next two conditions of sahih hadith, namely strong memory (dhabit) and trustworthy ('adil). Syu'bah bin al-Hajjaj was once asked a question:

"Whose hadith narration needs to be rejected?" Syu'bah replied: "When a narrator narrates a hadith from some famous narrators while the hadith was never in the knowledge of the narrator, then the hadith narrated by them should be rejected. When a narrator is accused of being a liar then the hadith narrated must be rejected. When a narrator is found to have 
made many mistakes, his narration is also rejected. When a narrator narrates a hadith and then the hadith has been agreed by the scholars as wrong, then this is also rejected. Whatever is narrated by a narrator other than the above then you should narrate from such narrator" (Salleh, 1993).

It is clear above that in the narration of hadith, the strength of memory (dhabit) and trustworthiness ('adil) are highly emphasized. Among the methods used by the narrator are face-to-face interviews and sometimes questionnaires. For example, when a narrator narrates a hadith from a deceased Sheikh, the narrator is asked:

"When were you born? When did you meet the Sheikh? Where did you find him?"

As narrated from 'Ufair Ibn-Ma'dan that Umar Ibn-Musa narrated a hadith from Khalid IbnMa'dan. So 'Ufair asked:

"Which year did you meet him?" He replied: "In $158 \mathrm{AH}$, in the Armenian war." I also said: "Fear Allah, O Sheikh, do not lie. Khalid died in $154 \mathrm{AH}$, plus he was never present in the Armenian war" (al-Asqolany, 1988).

Interviews and questionnaires can also be conducted to neighbors, family members, or classmates to ensure the strength of memory (dhabit) and reliability of the narrator ('adil).

In addition, hadith collectors can first gather information about the narrator from scholars who write about the narrator's personality or make their own research on the hadith that has been narrated by the narrator that they are going to meet. Sometimes hadith collectors have been able to assess the condition of the narrator through the hadiths that have been narrated.

Once a hadith is obtained by a hadith collector from a hadith narrator, a hadith will not be given the rank of sahih hadith directly even if it fulfills the previous three conditions. Once the hadith is obtained, the hadith collector still needs to analyze the hadith obtained earlier so that it does not have any irregularities (Syaz) or any defects ('illah).

Irregularities can occur in sanad or matan where the narrated hadith cannot contradict other narrations narrated by a more reliable narrator. Among the examples of irregularities in matan is missing a narrator the chain than it should be. Irregularities in the matan are usually errors in sentence structure that lead to other interpretations even though using the same word. The same can happen in finding defects in hadith. Usually, the defect lies in the matan or sanad. However, the defects in hadith are mostly hidden and only those who are experts in the field of hadith can discover the defects. In order to find irregularities and defects, hadith needs to be compared between one narration to another. The irregularities and defects arising from comparisons need to be studied whether the differences lie in the text or in terms of the meaning of the hadith. 


\section{Determination of Respondents in the Hadith Collection Method based on the practice of Imam Bukhari}

Based on the process of collecting sahih hadith above, the analysis of the five conditions of sahih hadith set by hadith scholars based on Islamic-based research methods have similarities from a technical aspect. The analysis of the five conditions of sahih hadith with a focus on the method of collecting the hadith of Imam Bukhari from the point of view of determining the respondents in the research method is as follows:

\section{The chain of Narrators is Connected}

In ensuring the chain connection, Imam Bukhari has taken a more cautious step in determining the respondents (in the context of the narrator's hadith). For hadith narrated using the words 'an and anna, Imam Bukhari requires the narrator to have met his teacher at least once in his life. This condition is important in the determination of the chain of transmission for Imam Bukhari. Compared to Imam Muslim, he does not require a meeting, it is enough to just live one time with his teacher that is when his teacher died, the narrator must have reached the appropriate age to listen to hadith (al-Shamali, 2002).

Based on the aspect of research methods, the act of Imam Bukhari which requires meeting a teacher is to ensure that the narrator of the hadith takes data from primary sources. The determination of respondents here can be interpreted as interviews or data taken must be from primary sources. This is to ensure that the data is not in doubt and is accurate. According to Marican (2005), primary data is original data collected specifically to answer research questions. It is data collected by the researcher himself to test the hypotheses in his study.

From another perspective, the actions of Imam Bukhari are more similar to what is named in conventional research as the determination of respondents based on purposive sampling. According to Creswell (2013), purposive sampling is a sampling procedure in which a group of subjects has certain characteristics as study informants. The researcher knows who the desired respondent is and goes to meet the respondent as opposed to convenience sampling which is taking anyone as a study informant. This is in line with what was executed by Imam Bukhari who has required only those who heard the hadith directly from his teacher to qualify the narrated hadith to be considered sahih hadith. Primary data collection and sampling are intended to provide an initial overview of the possibility that this method of hadith collection can meet the characteristics of a field study. This also takes into account the features of observations, questionnaires, and interviews as will be explained later.

\section{Ensuring the narrator has a strong memory (Dhabit)}

After identifying the narrator to be met, the hadith collector needs to assess the strength of the narrator's memory first to meet the second condition. To assess the strength of the narrator's memory, the hadith collector will usually ask the people around him about the level of memory of a narrator. Among the people interviewed were his family members, teachers, students, neighbors, and the local community. This is also not something foreign in research methods. An interview is among the main methods in collecting data. Similarly, the respondents selected to ensure the strength of the narrator's memory such as family members, teachers, students, narrator's neighbors, and the local community have in fact become accustomed and recognized in historical or biographical related research. 
In addition, in ensuring the strength of the narrator's memory, the hadith collector can also analyze the hadith that has been collected. Hadith collectors compare hadith narrated by a narrator with narrators who are more recognized by hadith scholars. For example, Imam Malik is very strict on the wording of hadith where he is very strict and careful in narrating hadith so as not to add even the slightest bit even the letters ba', ta' or ya'(Salleh, 1993). Therefore, text comparisons are necessary. In research methods, this can be counted as text analysis. Factors that can lead to disputes on the strength of a narrator's memory are such as making obvious mistakes, negligence in listening to hadith, doubts arise, faulting with other narrators, poor memory, aloneness, and unknown narrators (Akailah et al., 2004). Therefore, usually, the accepted hadith will always be analyzed for its content so as not to contradict the narration of people who have been proven to have a strong memory or do not violate the principles of religion.

In the context of current research, the determination of respondents should also look at the knowledge, expertise, and reliability of the selected respondents. Hence, the method of Imam Bukhari and other hadith scholars, looking at the strength of the memory of the respondent (narrator) is vital in ensuring quality research findings, validity, and high reliability.

\section{Ensure the narrator is trustworthy ('adil)}

The process of ensuring the trustworthiness of the narrator is the most important part of the method of collecting hadith. There are five conditions that must be met in order to be trustworthy as mentioned above. Thus, the factors that cause the narrator to be unreliable are deceit, accused of deceiving, fasiq in words and deeds, being unknown, and heretics in aqidah (Akailah et al., 2004). Even whoever utters abusive words and gives nonsensical expressions, then the hadith collectors will stay away from him and they will not narrate the hadiths from the narrator. That is how Imam Bukhari rejected the hadith narrated by alNadhar bin Muttarrif because Yahya bin Said al-Qattan did not narrate from him. Yahya bin Said al-Qattan said:

"I heard al-Nadhar say: If I do not narrate the hadith to you then his mother is an adulterer, because of these words I left his narration".

To confirm the trustworthiness of the narrator, usually, observational techniques are used in the determination of respondents. For example, Syu'bah bin al-Hajjaj once said:

"The thing that made me happiest was that I met a man who came from Makkah and I asked about Abi al-Zubir until I went to Makkah (to meet him) and heard a hadith from him. While I was by his side, suddenly a man came asking something. Then he lied to the man, then I asked him: Why did you lie to a Muslim man? He replied: Because the man has made me angry. (Syu'bah said) I asked him again: He made you angry, so you lied to him? Syu'bah said again: In my chest (knowledge) there are 400 hadith taken from Abi al-Zubir and by Allah I will not narrate any of them to you forever" (Salleh, 1993).

The same goes for the interviews as described above. Some narrators may be more interested in using questionnaires. 
4. Analyze sanad and matan from irregularities (Syaz) and defect ('illah).

Among the most obvious examples in this regard is the hadith narrated by Abu Daud and alTirmizi which consists of the hadith of Abdul Wahid bin Ziyad from al-A'masy from Abi Hurairah in marfu':

"If any of you prays two rak'ahs before the dawn prayer, he should lie at his right side."

Regarding this hadith, many narrators contradict Abdul Wahid bin Ziyad even though he has a trusted narrator. Most of the narrators narrate this hadith by looking at the action of Rasulullah s.a.w and not from the speech of Rasulullah s.a.w. Only Abdul Wahid from the disciples of al-A'masy narrated the hadith with the above words. Another narrator narrates:

"Indeed, the Prophet s.a.w afer he had prayed two rak'ahs of dawn, he lied on the right rib" (Salleh, 1993).

Based on the above example, it can be concluded that hadith scholars will usually use text analysis, content analysis, and comparative analysis in analyzing the sanad and matan from any irregularities (Syaz) and defects ('illah). The irregularities of the hadith narrated by Abdul Wahid can be detected after his text is compared with the text of the hadith of other students of al-A'masy. The obvious differences in the text have lowered the standard of the hadith narrated by Abdul Wahid. The same is true if the content of the hadith is analyzed. The structure of the hadith verse narrated by Abdul Wahid is an instruction verse that leads to the obligatory law or sunnah while the actual narration is only reporting the actions of Rasulullah s.a.w after the Subuh sunnah prayer.

\section{Conclusions and Recommendations of The Future Study}

Based on the above discussion, there are three things that can be concluded. First, based on the comparison between the hadith collection method with the characteristics of the data collection method instruments in the research method, there are similarities from a technical point of view. Second, the process of collecting hadith based on the research methods perspective has the potential to be used as a data collection method for studies that require reliable and accepted data, especially studies involving religion. Third, the method of determining the respondents in the hadith collection method has a high level of validity and reliability of the data.

Based on these findings, it is proposed for further research in the future to look at the method of collecting hadith from the aspect of research design. This is based on the principle that if this method of hadith collection is suitable as an Islamic-based data collection method, can the same method be reviewed from the perspective of Islamic-based research design? Therefore, a more in-depth study needs to be carried out so that this method of hadith collection can be utilized and compiled systematically in the form of scientific methods of Islamic-based research methods. Indirectly, this makes a significant contribution, especially to studies made on Islam that require an Islamic-based research method that has high reliability, especially studies that will involve the construction of law. 


\section{Acknowledgment}

This paper is part of the research findings entitled Research Design in IslamicBased Research Methods [(RUI)1001/CISDEV/8016060] which was funded by Research University Individual (RUI) grant, Universiti Sains Malaysia.

\section{Corresponding Author}

Shahir Akram Hassan

Centre for Islamic Development Management Studies (ISDEV), Universiti Sains Malaysia, 11800 USM, Penang

Email: shahirakram@usm.my

\section{References}

Abdullah, M. H. (1986). Peranan dan Metodologi Hadis. Kuala Lumpur: Bahagian Hal Ehwal Islam, Jabatan Perdana Menteri.

Al-Asqolany. (1988). Lisan al-Mizan. Beirut: Darul Fikr.

Al-Asqolany. (t.t). Fathul Bari Fi Syarhi Shahih al-Bukhari. Kaherah: Maktabah Mesir.

Al-Shamali, Y. (2002). Al-Wadih Fi Manahij al-Muhaddithin. Amman: Darul Hamid.

Creswell, J. W. (2013). Qualitative inquiry and research design: Choosing among five tradition. Sage Publication.

Greener, S. (2008). Business research methods. BookBoon.

Hassan, S. A. (2019). Data Collection Instruments based on The Definition of Hadith. International Journal of Academic Research in Business and Social Sciences, 9(12), 685-693.

Said, N. A., \& Khairuldin. (2017). Freedom of Speech in Islam and its Connection with Street Demonstrations. International Journal of Academic Research in Business and Social Sciences, 7(4), 122-129.

Marican, S. (2005). Kaedah Penyelidikan Sains Sosial. Petaling jaya: Pearson Malaysia Sdn Bhd.

Salleh, S. (1993). Ilmu Hadith-Satu pengenalan dan kajian, terj Ariffin Omar \& Mohd. Nor Ngah. Kuala Lumpur: Dewan Bahasa dan Pustaka.

Hassan, S. A., \& Khairuldin, W. M. K. F. W. (2020). Research Design Based on Fatwa Making Process: An Exploratory Study. International Journal of Higher Education, 9(6), 241246. 